\title{
Jurist-Diction
}

Volume 4 No. 1, Januari 2021

\section{Pembatasan Permohonan Pembatalan Penetapan Hasil Penghitungan Suara Pemilihan Kepala Daerah}

\author{
Ibnu Rizky Pratama \\ Ibnu23rizky@gmail.com \\ Universitas Airlangga
}

How to cite:
Ibnu Rizky Pratama,
'Pembatasan Permohonan
Pembatalan Penetapan Hasil
Penghitungan Suara Pemilihan
Kepala Daerah' (2021) Vol. 4
No. 1 Jurist-Diction.

Histori artikel:

Submit 16 November 2020;

Diterima 9 Desember 2020;

Diterbitkan 5 Januari 2021.

DOI:

10.20473/jd.v4i1.24296

p-ISSN: $2721-8392$

e-ISSN: $2655-8297$

\section{Abstract}

Regional Head Election is an orderly constitutional opportunity for a peaceful and honest competition to gain power as regulated in Article 18, section (4) of the 1945 Constitution of the Republic of Indonesia. The success of Regional Head Elections is not only seen from the voting process, but also it must be accompanied by a good Regional Head Election dispute resolution process. Regarding the settlement of Regional Head Election dispute, until now there are still problems in resolving disputes over the results of Regional Head Elections. In Article 158 of Law Number 10 of 2016 Regarding the Second Amendment to Law Number 1 of 2015 Regarding the Establishment of Government Regulations In lieu of Law Number 1 of 2014 Regarding the Election of Governor, Regent and Mayor Becoming a law, it regulates the requirements for an application for the cancellation of the determination of the vote count results, namely for disputes over the results of the Regional Head Election which can be submitted to the Constitutional Court, requirement for the maximum difference in votes between $0.5 \%$ to $2 \%$.

Keywords: Regional Head Election; Result Dispute; Constitutional Court; Ratio Legis

\begin{abstract}
Abstrak
Pemilihan Kepala Daerah merupakan kesempatan konstitusional yang teratur bagi suatu persaingan damai dan jujur untuk memperoleh kekuasaan sebagaimana diatur pada Pasal 18 ayat (4) UUD NRI 1945. Kesuksesan Pilkada tidak hanya dilihat dari proses pemungutan suara saja, namun juga harus dibarengi dengan proses penyelesain sengketa Pilkada yang baik. Terkait dengan penyelesain sengketa Pilkada, sampai saat ini masih terdapat permasalahan pada penyelesaian sengketa hasil Pilkada. Pada Pasal 158 UU Nomor 10 Tahun 2016 tentang Perubahan Kedua Atas Undang-Undang Nomor 1 Tahun 2015 Tentang Penetapan Peraturan Pemerintah Pengganti UndangUndang Nomor 1 Tahun 2014 Tentang Pemilihan Gubernur, Bupati, Dan Walikota Menjadi Undang-Undang diatur mengenai syarat permohonan pembatalan penetapan hasil penghitungan suara yaitu untuk sengketa hasil Pilkada yang dapat diajukan ke MK, syarat selisih suara maksimal antara 0,5 persen sampai 2 persen.

Kata Kunci: Pemilihan Kepala Daerah; Sengketa Hasil; Mahkamah Konstitusi; Ratio Legis.
\end{abstract}




\section{Pendahuluan}

Menurut Juan Linz dalam bukunya Vleavages Ideologies and Party Systems, sistem pemerintahan dapat disebut demokratis apabila ia memberi kesempatan konstitusional yang teratur bagi suatu persaingan damai dan jujur untuk memperoleh kekuasaan. ${ }^{1}$ Di Indonesia sendiri konsep demokrasi tertuang dalam Pasal 1 ayat (2) Undang-Undang Dasar NRI 1945, yang menjelaskan bahwa kedaulatan berada di tangan rakyat dan dilaksanakan menurut Undang-Undang Dasar, hal ini menunjukan bahwa demokrasi adalah hak yang dapat dibahasakan mutlak dimiliki rakyat dan dijamin dalam konstitusi. Oleh karena itu Pemilu adalah suatu syarat yang mutlak bagi negara demokrasi untuk melaksanakan kedaulatan rakyat. ${ }^{2}$ Mengenai pemilihan kepala daerah atau Pilkada ketentuan Pasal 18 ayat (4) Undang-Undang Dasar Negara Republik Indonesia Tahun 1945 menyebutkan bahwa Gubernur, Bupati, dan Walikota masing-masing sebagai kepala pemerintah daerah provinsi, kabupaten, dan kota dipilih secara demokratis. ${ }^{3}$ Ketentuan Pasal 18 ayat (4) UUD NRI 1945 tersebut mencermikan bahwa Indonesia merupakan negara yang menjunjung tinggi demokrasi.

Berbicara mengenai pemilihan kepala daerah, pada 9 Desember 2020 KPU provinsi, kabupaten/kota akan menyelenggarakan pemilihan gubernur, bupati, dan walikota di 270 daerah, dengan rincian sembilan pemlihan gubernur, 224 pemilihan bupati, dan 37 pemilihan walikota. ${ }^{4}$ Dalam Pilkada serentak tahun 2020 ini adanya peluang untuk adanya sengketa sangatlah besar. Tercatat pada tanggal 31 Juli 2019 terdapat 329 permohonan diajukan ke MK. ${ }^{5}$ Dari dasar tersebut baik sengketa proses pemilihan, maupun sengketa hasil pemilu merupakan hal yang lumrah. Dalam

\footnotetext{
1 Parulian Donald, Menggugat Pemilu (Pustaka Sinar Harapan 1997).[2].

2 Titik triwulan tutik, Kontruksi hukum tata negara indonesia pasca amandemen UUD 1945 (Kencana 2011).[331].

3 Undang-Undang Dasar Negara Republik Indonesia 1945 Pasal 18.

4 Nur Azizah Rizki Astuti, 'Pilkada Serentak Digelar 23 September 2020, Ini Tahapannya!' (detik.com, 2020) < detik.com/berita/d-4615384/pilkada-serentak-digelar-23-september-2020-ini-tahapannya $>$ diakses pada 08 Juli 2019.

5 CNN, 'Jumlah Sengketa Pemilu 2019 di MK Bertambah Jadi 340 Kasus' (CNN Indonesia) <https://www.cnnindonesia.com/nasional/20190531134239-32-400029/jumlah-sengketa-pemilu-2019-di-mk-bertambah-jadi-340-kasus> diakses pada 01 Juli 2019.
} 
peenyelenggaraan Pilkada terdapat dua jenis sengketa yaitu sengketa proses dan sengketa hasil. Dua sengketa tersebut ditangi oleh lembaga yang berbeda dimana sengketa hasil Pilkada ditangani oleh MK dan sengketa proses Pilkada ditangani oleh lembaga lain selain MK seperti KPU, Bawaslu, Gakkumdu, PN, PTUN, dan DKPP.

Lebih spesifik pada proses penyelesaian perselisihan hasil pilkada, sesuai dengan ketentuan Pasal 157 ayat (3) UU Nomor 10 Tahun 2016 tentang Pilkada bahwa perolehan suara tahap akhir hasil Pemilihan diperiksa dan diadili oleh Mahkamah Konstitusi sampai dibentuknya badan peradilan khusus. Di ayat selanjutnya yaitu di ayat 4 peserta pemilihan yang tidak puas dengan penetapan KPU mengenai hasil rekapitulasi suara dapat mengajukan permohonan pembatalan penetapan hasil penghitungan perolehan suara oleh KPU Provinsi atau KPU Kabupaten/Kota kepada Mahkamah Konstitusi. ${ }^{6}$ Namun, di dalam ketentuan pasal selanjutnya yaitu pasal 158 yang pada intinya berisi tentang pengaturan syarat permohonan pembatalan penetapan hasil penghitungan suara yaitu untuk sengketa hasil yang dapat diajukan ke MK, syarat selisihnya maksimal antara 0,5 persen sampai 2 persen. Dimana prosentase tersebut ditentukan dengan jumlah penduduk yang ada pada provinsi, kota/kabupaten. ${ }^{7}$ Ketentuan Pasal 158 ini menjadi syarat mutlak bagi peserta Pilkada yang ingin mengajukan permohonan pembatalah penetapan hasil perhitungan ke MK.

Disisi lain dalam konteks penyelesaian sengketa hasil pemilihan kepala daerah, MK disini dapat dikatakan sebagai pelaksana dari UU Nomor 10 Tahun 2016 tentang Perubahan Kedua Atas Undang-Undang Nomor 1 Tahun 2015 Tentang Penetapan Peraturan Pemerintah Pengganti Undang-Undang Nomor 1 Tahun 2014 Tentang Pemilihan Gubernur, Bupati, Dan Walikota Menjadi UndangUndang, ini terbukti dengan adanya aturan yang sejalan dengan pengaturan pasal 158. Dalam Peraturan Mahkamah Konstitusi (PMK) nomor 5 Tahun 2017 tentang

${ }^{6}$ Undang-Undang Nomor 10 Tahun 2016 tentang Perubahan Kedua Atas UndangUndang Nomor 1 Tahun 2015 Tentang Penetapan Peraturan Pemerintah Pengganti UndangUndang Nomor 1 Tahun 2014 Tentang Pemilihan Gubernur, Bupati, Dan Walikota Menjadi Undang-Undang Pasal 157.

ibid. Pasal 158. 
pedoman beracara dalam perkara perselisihan hasil pemilihan gubernur, bupati, dan wali kota juga diatur ketentuan yang sama bagi para peserta pemilihan yang akan mengajukan permohonan ke MK, diatur pada ketentuan pasal 7 PMK ini. ${ }^{8}$ Terjadi perbedaan mengenai penanganan sengketa hasil Pilkada oleh MK dari sebelum berlakunya UU Nomor 10 Tahun 2016 tentang Perubahan Kedua Atas Undang-Undang Nomor 1 Tahun 2015 tentang Penetapan Peraturan Pemerintah Pengganti Undang-Undang Nomor 1 Tahun 2014 tentang Pemilihan Gubernur, Bupati, Dan Walikota Menjadi Undang-Undang dengan sesudah berlakunnya UU tersebut. Sejak sengketa hasil pemilu tahun 2009, putusan MK lebih mendasarkan dan menggunakan pendekatan substantial justice yang mempersoalkan electoral process. Mahkamah Konstitusi disini secara tegas menunjukan dirinya mempunyai kewenangan untuk mempersoalkan judicial process untuk memastikan kualitas bukan sekedar kuantitas pemilu dengan menyatakan secara materiil telah terjadi pelanggaran ketentuan Pilkada yang berpengaruh pada perolehan suara. ${ }^{9}$ Sebagai contoh Putusan MK nomor 41/PHPU.D-VI/2008 tentang Perselisihan Hasil Pilkada Jawa Timur 2008 dalam putusannya, MK mempertimbangkan pelanggaran yang bersifat terstruktur, sistematis, dan masif (TSM) yang mempengaruhi hasil suara, dimana pertimbangan ini lebih pada proses pemilihan bukan hasil pemilihan sebagaimana dijelaskan dalam UU Pilkada. Hal tersebut membuktikan bahwa MK mengutamakan keadilan substantif dengan tidak hanya terkekang pada penafsiran sempit Undang-undang saja.

Dengan kata lain dalam penyelesaian sengketa hasil Pilkada MK tidak lagi mempertimbangkan pelanggaran-pelanggaran dalam proses Pilkada yang mempengaruhi hasil perhitungan, MK hanya melaksanakan bunyi UU Nomor 10 Tahun 2016 termasuk Pasal 158 secara mutlak. Dengan begitu otomatis hanya pemohon yang memenuhi ambang batas maksimal antara 0,5 \% - 2\% selisih suara

8 Peraturan Mahkamah Konstitusi Nomor 5 Tahun 2017 tentang pedomanm beracara dalam perkara perselisihan hasil pemilihan gubernur, bupati, dan wali kota Pasal 7.

9 Pusat Penelitian dan Pengkajian Mahkamah Konstitusi Republik Indonesia, Tafsir Konstitusional Pelanggaran Pemilukada yang Bersifat Sistematis, Terstruktur dan Masif (2011).[4]. 
saja yang akan ditindaklanjuti oleh MK, bukan selisih suara yang lebih atau bahkan kurang dari ambang batas tersebut. Jika MK demikian maka penerapan Pasal 158 akan berpotensi mengabaikan keadilan dan persamaan dihadapan hukum bagi para pihak yang akan mengajukan permohonan tentang pembatalan penetapan hasil Pilkada ke MK. Mengingat putusan MK bersifat final dan mengikat yang berarti menutup peluang adanya upaya hukum, maka kejelasan mengenai penerapan pasal 158 UU Pilkada ini sangat penting karena berdampak bagi para pencari keadilan, yaitu para pihak yang terlibat dalam pemilihan kepala daerah.

\section{Ratio Legis Pengaturan Pasal 158 Undang-Undang Nomor 10 Tahun 2016 tentang Pemilihan Kepala Daerah}

Pasal 158 Undang-undang pemilihan kepala daerah merupakan pasal yang memuat mengenai ketentuan ambang batas pengajuan permohonan pembatalan hasil pemilihan keapala daerah. Ambang batas dalam Pasal ini adalah prosentase perbedaan hasil suara antara $0,5 \%-2 \%$, dimana prosentase tersebut disesuaikan dengan jumlam penduduk di daerah pemilihan. Ambang batas dalam pasal ini menjadi syarat bagi peserta pemilihan kepala daerah untuk mengajukan permohonan pembatalan hasil pemilihan kepala daerah. Berikut merupakan ambang batas yang diatur dalam Pasal 158:10

1) Peserta pemilihan Gubernur dan Wakil Gubernur dapat mengajukan permohonan pembatalan penetapan hasil penghitungan suara dengan ketentuan:

a. provinsi dengan jumlah penduduk sampai dengan 2.000.000 (dua juta) jiwa, pengajuan perselisihan perolehan suara dilakukan jika terdapat perbedaan paling banyak sebesar 2\% (dua persen) dari total suara sah hasil penghitungan suara tahap akhir yang ditetapkan oleh KPU Provinsi;

b. provinsi dengan jumlah penduduk lebih dari 2.000 .000 (dua juta) sampai dengan 6.000.000 (enam juta), pengajuan perselisihan perolehan suara dilakukan jika terdapat perbedaan paling banyak sebesar 1,5\% (satu koma lima persen) dari total suara sah hasil penghitungan suara tahap akhir yang ditetapkan oleh KPU Provinsi;

c. provinsi dengan jumlah penduduk lebih dari 6.000 .000 (enam juta) sampai 
dengan 12.000.000 (dua belas juta) jiwa, pengajuan perselisihan perolehan suara dilakukan jika terdapat perbedaan paling banyak sebesar 1\% (satu persen) dari total suara sah hasil penghitungan suara tahap akhir yang ditetapkan oleh KPU Provinsi; dan

d. provinsi dengan jumlah penduduk lebih dari 12.000.000 (dua belas juta) jiwa, pengajuan perselisihan perolehan suara dilakukan jika terdapat perbedaan paling banyak sebesar $0,5 \%$ (nol koma lima persen) dari total suara sah hasil penghitungan suara tahap akhir yang ditetapkan oleh KPU Provinsi

2) Peserta Pemilihan Bupati dan Wakil Bupati serta Walikota dan Wakil Walikota dapat mengajukan permohonan pembatalan penetapan hasil penghitungan perolehan suara dengan ketentuan:

a. kabupaten/kota dengan jumlah penduduk sampai dengan 250.000 (dua ratus lima puluh ribu) jiwa, pengajuan perselisihan perolehan suara dilakukan jika terdapat perbedaan paling banyak sebesar $2 \%$ (dua persen) dari total suara sah hasil penghitungan suara tahap akhir yang ditetapkan oleh KPU Kabupaten/ Kota;

b. kabupaten/kota dengan jumlah penduduk lebih dari 250.000 (dua ratus lima puluh ribu) jiwa sampai dengan 500.000 (lima ratus ribu) jiwa, pengajuan perselisihan perolehan suara dilakukan apabila terdapat perbedaan paling banyak sebesar 1,5\% (satu koma lima persen) dari total suara sah hasil penghitungan suara tahap akhir yang ditetapkan oleh KPU Kabupaten/Kota;

c. kabupaten/kota dengan jumlah penduduk lebih dari 500.000 (lima ratus ribu) jiwa sampai dengan 1.000.000 (satu juta) jiwa, pengajuan perselisihan perolehan suara dilakukan jika terdapat perbedaan paling banyak sebesar 1\% (satu persen) dari total suara sah hasil penghitungan suara tahap akhir KPU Kabupaten/Kota; dan

d. kabupaten/kota dengan jumlah penduduk lebih dari 1.000 .000 (satu juta) jiwa, pengajuan perselisihan perolehan suara dilakukan jika terdapat perbedaan paling banyak sebesar $0,5 \%$ (nol koma lima persen) dari total suara sah hasil penghitungan suara tahap akhir KPU Kabupaten/Kota.

Perkembangan Pasal 158 sejak diatur pertama kali di dalam Perpu Nomor 1 Tahun 2014 tidak mengalami perubahan yang signifikan. Sampai kepada berlakunya Undang-Undang Nomor 10 Tahun 2016 yang menjadi payung hukum Pilkada sekarang, tidak banyak perubahan yang terjadi dalam ketentuan Pasal 158 ini. Namun, tidak adanya perubahan yang signifikan dalam Pasal 158 bukan berarti tidak ada yang mempermasalahkan ketentuan Pasal tersebut. Hal tersebut dibuktikan dengan adanya putusan MK yang berkaitan dengan permohonan pengujian Pasal 
158 kepada MK seperti PMK Nomor 51/PUU-XIII/2015, PMK Nomor 58/PUUXIII/2015, dan PMK Nomor 123/PHP.BIP-XIV/2016.

Alasan diberlakunya Pasal 158 yang diatur dalam Perpu Nomor 1 Tahun 2014 dapat dilihat dari kejadian di dalam proses penyelesaian sengketa hasil Pilkada sebelum dibelakukannya pasal ini. Diawali dengan diberlakukannya Pasal 236C UU Pemda yang mengatur bahwa penyelesaian sengketa hasil Pilkada dialihkan dari yang awalnya berada di MA menjadi kewenangan MK. Hal tersebut mengakibatkan ratusan permohonan sengketa hasil Pilkada masuk ke MK yang menjadikan MK sebagai keranjang sampah dalam penyelenggaraan Pilkada. Ditambah dalam menangani sengketa hasil Pilkada, MK tidak memiliki tolak ukur yang jelas mengenai pelanggaran yang bersifat terstuktur, sistematis, dan masif (TSM). Perlu diingat sebelum berlakunnya Pasal 158, MK dalam penanganan sengketa hasil Pilkada masih mempertimbangkan pelanggaran di dalam proses Pilkada yang mempengaruhi hasil suara. Salah satu akibanya adalah ditangkapnya ketua MK Aqil Mochtar oleh Komisi Pemberantasan Korupsi (KPK) karena menerima suap penanganan sengketa hasil Pilkada. Kasus Aqil Mochtar ini juga menjadi salah satu alasan pemerintah dalam Perpu Nomor 1 Tahun 2014 mengalihkan kewenangan penyelesaian sengketa hasil Pilkada kepada MA. Dari penjelasan tersebut dapat dimaknai bahwa diaturnya Pasal 158 adalah ditujukan agar MK tidak lagi terperosok pada batu uji pelanggaran terstuktur, sistematis, dan masif (TSM) yang belum memiliki tolak ukur yang jelas. ${ }^{11}$

Diketahui bahwa pengaturan Pasal 158 pertama kali muncul dalam ketentuan Perpu Nomor 1 Tahun 2014. Peraturan Pemerintah Pengganti Undang-Undang adalah Peraturan Perundang-undangan yang ditetapkan oleh Presiden dalam hal ihwal kegentingan yang memaksa, artinya ketentuan Pasal 158 tersebut awalnya dirumuskan oleh pemerintah. ${ }^{12}$ Dalam pembahasan perubahan pertama atas

${ }^{11}$ Risalah Rapat Panja DPR RI, Pembahasan subtansi materi RUU tentang Perubahan UU No.1 Tahun 2015 (PILKADA), Kamis, 1 Februari 2015.[17].

${ }_{12}$ Undang-Undang Nomor 12 Tahun 2011 tentang Pembentukan Peraturan Perundang-Undangan, Pasal 1. 
Undang-Undang Nomor 1 Tahun 2015 menjelaskan bahwa ketentuan Pasal 158 tersebut bertujan untuk membatasi pintu-pintu pengujian terhadap hasil pemilihan kepala daerah. Pembatasan tersebut ditujukan agar perkara yang masuk kepada MA tidak terlalu banyak sehingga tidak memberatkan MA mengingat banyaknya perkara yang sudah masuk dan akan ditangani oleh MA. ${ }^{13}$ Menurut pemerintah MA merupakan lembaga yang paling tepat menangani sengketa hasil pemilihan kepala daerah setelah adanya putusan MK Nomor 97/PUU-XII/2013 yang menyatakan bahwa MK tidak berwenang untuk menangani sengketa hasil pemilihan kepala daerah. Dalam pembahasan ini tidak banyak membahas mengenai ketentuan Pasal 158 karena pembentuk Undang-Undang lebih banyak membahas ketentuanketentuan lain, salah satunya adalah Pasal 157 yang mengatur mengenai lembaga yang berwenang menangani sengketa hasil pemilihan kepala daerah.

Pada akhirnya disepakati bahwa lembaga yang berwenang menangani sengketa hasil pemilihan kepala daerah adalah peradilan khusus dimana selama belum terbentuk peradilan khusus maka yang berwenang mengadili adalah MK. Berkaitan Pasal 158 disepakati dengan dasar bahwa ketententuan pasal tersebut yang awalnya ditujukan untuk membatasi pintu-pintu pengujian terhadap hasil pemilihan kepala daerah sehingga tidak memberatkan MA dalam penanganan sengketa hasil Pilkada nantinya juga akan sama akibatnya kepada MK. Perbedaan yang ada terdapat pada waktu penyelesaian perkara, dimana ketika MA masih memiliki kewenangan untuk menyelesaikan sengketa hasil Pilkada, waktu penyelesainnya hanya 14 hari sebagaimana diatur pada Pasal 157 ayat (5) UU Nomor 1 Tahun 2015. Berbeda ketika kewenangan penyelesaian sengketa hasil Pilkada berada pada MK, dimana MK diberikan waktu 45 hari dalam memutus sengketa hasil Pilkada sebagaimana diatur pada Pasal 157 ayat (8) UU Nomor 10 Tahun 2016. Perbedaan waktu penyelesaian yang diberikan lebih lama kepada MK disebabkan karena kewenangan MK dalam menyelesaikan sengketa hasil Pilkada merupakan kewenangan tambahan dan bukan merupakan kewenangan yang diberikan secara

${ }^{13}$ Op.Cit. [24-25]. 
langsung oleh konstitusi sebagaimana diatur secara limitatif pada Pasal 24C UUD NRI 1945. Waktu penyelesaian yang diberikan lebih lama pada MK juga dapat dilihat sebagai upaya untuk mempermudah MK dalam memutus sengketa hasil Pilkada karena banyaknya perkara yang ditangani oleh MK sendiri.

Alasan pembentuk undang-undang merumuskan pengaturan Pasal 158 juga dapat ditinjau dari Putusan MK tentang pengujian undang-undang pilkada terhadap UUD NRI 1945. Dalam Putusan MK Nomor 51/PUU-XIII/2015 dijelaskan bahwa pada pesidangan tanggal 21 Mei 2015 pembentuk Undang-Undang dalam hal ini DPR telah memberikan keterangan lisan terhadap permohonan para pemohon yang menyatakan bahwa Pasal 158 Undang-Undang Nomor 8 Tahun 2015 bertentangan dengan UUD NRI 1945. DPR menjelaskan bahwa Pasal 158 dirumuskan untuk menjamin kepastian hukum atas hasil Pilkada. Berkaitan dengan selisih perolehan suara yang diatur dalam Pasal 158 ditujukan untuk menjamin adanya jumlah suara yang dirugikan secara signifikan, dimana prosentase ambang batas disesuaikan dengan jumlah penduduk di daerah terkait. ${ }^{14}$

Dalam kurun waktu berlakunya Undang-Undang Nomor 8 Tahun 2015 yang memuat pengaturan Pasal 158, memang MK beberapa kali mendapatkan permohonan pengujian Undang-Undang yang para pemohonnya menyatakan bahwa Pasal 158 bertentangan dengan UUD NRI 1945. Terhadap batu uji permohonan tersebut MK dalam putusannya cenderung memberikan penguatan kepada dalil dari pembentuk Undang-Undang. Pertama, ratio decidendi pada Putusan MK Nomor 51/PUU-XIII/2015 terhadap dalil para pemohon yang menyatakan bahwa Pasal 158 memberi batasan bagi peserta pemilihan kepala daerah dalam hal terjadi pelanggaran yang bersifat terstruktur, sistematis, dan masif maka peserta pilkada tidak dapat mengajukan permohonan pembatalan hasil perhitungan suara kepada MK. Menurut MK, tidak semua pembatasan berarti bertentangan dengan UUD NRI 1945 apabila pembatasannya menjamin pengakuan, penghormatan atas hak dan kebebasan orang lain, serta untuk memenuhi tuntutan yang adil sesuai dengan moral, nilai-nilai agama,

\footnotetext{
${ }^{14}$ Putusan Mahkamah Konstitusi Nomor 51/PUU-XIII/2015.[87].
} 
keamanan, dan ketertiban umum. MK juga menjelaskan bahwa pembatasan dalam ketentuan Pasal 158 tersebut merupakan kebijakan hukum terbuka (open legal policy) pembentuk Undang-Undang, pembatasan tersebut juga logis dan dapat diterima secara hukum karena ditunjukan untuk mengukur signifikansi perolehan suara calon kepala daerah. ${ }^{15}$ Kedua, ratio decidendi pada Putusan MK Nomor 58/PUU-XIII/2015 menjelaskan bahwa Pasal 158 merupakan upaya dari pembentuk Undang-Undang untuk mendorong terbangunnya etika dan budaya poliitik yang semakin dewasa. Upaya tersebut dilakukan dengan cara merumuskan norma Undang-Undang yang mengatur bahwa peserta Pilkada tidak dapat dengan serta merta menggugat hasil perhitungan suara ke MK dengan dasar perhitungan yang sulit diterima oleh penalaran yang wajar. ${ }^{16}$ Ketiga, ratio decidendi Putusan MK Nomor 123/PHP.BUP-XIV/2016 terhadap dalil para pemohon yang menyatakan bahwa MK harus mengabaikan ketentuan Pasal 158 karena mengekang penegakan keadilan substantif oleh MK. Dalam putusannya Mahakamah berpendapat sebagai berikut: ${ }^{17}$

1. Terdapat perbedaan antara Pilkada sebelum keluarnya Putusan MK Nomor 97/ PUU.XII/2013 dengan Pilkada setelah keluarnya Putusan MK tersebut. Sebelum keluarnya Putusan MK Nomor 97/PUU.XII/2013 Pilkada termasuk ke dalam rezim pemilu, sedangkan setelah munculnya Putusan MK tersebut Pilkada tidak termasuk kedalam rezim Pemilu. Perbedaan tersebut menghasilkan Konsekuensi hukum yang juga berbeda. Di saat Pilkada termasuk rezim pemilu maka kewenangan MK dalam mengadili sengketa hasilnya didasarkan pada ketentuan Pasal 24C ayat (1) UUD NRI 1945, sehingga dalam pelaksanaan kewenangannya MK memiliki fungsi dan peran sebagai pengawal konstitusi (the guardian of constitution). Fungsi dan peran ini menjadikan MK memiliki keleluasaan dalam melaksanakan kewenangannya. Keleluasaan ini yang menjadikan putusanputusan MK mengenai sengketa hasil Pilkada dahulu memiliki dimensi terobosan hukum. Contohnya adalah MK tidak hanya mengadili perselisihan hasil saja, namun juga meliputi pelanggaran dalam proses pemilihan yang memiliki dampak pada hasil suara atau dikenal dengan pelanggaran terstruktur, sitematis, dan masif (TSM). Berbeda dengan ketentuan Undang-Undang Nomor 8 Tahun 2015 yang memposisikan Pikada di luar dari rezim pemilu sesuai dengan Putusan MK Nomor 97/PUU.XII/2013 dan memberikan batasan-batasan yang jelas kepada MK dalam pelaksanaan kewenangannya.

\footnotetext{
15 ibid.[107].

16 Putusan Mahkmah Konstitusi Nomor 58/PUU-XIII/2015.[36].

17 Putusan Mahkmah Konstitusi Nomor 123/PHP.BUP-XIV/2016.
} 
2. Kewenangan MK yang diberikan oleh Pasal 157 Undang-Undang Nomor 8 Tahun 2015 bersifat non permanen dan transisinonal sampai dibentuknya peradilan Khusus. Selain itu kewenangan MK diatur secara limitatif dalam Pasal 24C ayat (1) UUD NRI 1945. Sehingga kewenangan MK yang diberikan oleh Undang-Undang Nomor 8 Tahun 2015 memiliki kualifikasi yang berbeda dengan kewenangan yang diberikan langsung oleh UUD NRI 1945. Dengan kata lain kewenangan MK mengadili sengketa hasil Pilkada dapat dikatakan sebagai kewenangan tambahan. Dengan dasar tersebut MK berpendapat bahwa dalam melaksanakan kewenangan tambahan tersebut, MK tunduk sepenuhnya pada Undang-Undang Nomor 8 Tahun 2015.

3. Tunduknya MK kepada kewenangan yang diatur di dalam Undang-Undang Nomor 8 Tahun 2015 tidak dapat diartikan bahwa MK telah mengalami degradasi dari hakikat keberadaanya sebagai Pengawal konstitusi (the guardian of constitution) menjadi sekedar lembaga yang hanya menjadi pelaksana Undangundang. Hal ini harus dimaknai bahwa MK tetaplah lembaga pengawal konstitusi, namun sedang diserahi kewenangan tambahan yang bersifat transisional untuk melaksanakan amanat Undang-Undang. Dengan dasar tersebut MK berpendapat bahwa pelaksanaan kewenangan yang diberikan Undang-Undang nomor 8 Tahun 2015 sejalan dengan kewajiban MK, dan hakim konstitusi sebagaimana sumpah yang telah diucapkan sebelum menjadi hakim konstitusi.

4. Pembentuk Undang-Undang berupaya membangun budaya hukum dan politik yang dewasa dengan membuat Pranata penyelesaian sengketa Pilkada. Tercermin dari ketentuan dalam Undang-Undang Nomor 8 Tahun 2015 mengatur penyelesaian sengketa proses Pilkada diserahkan kepada lembaga di luar MK. Artinya perselisihan yang diberikan kepada MK untuk diselesaikan adalah benar-benar merupakan sengketa hasil Pilkada.

5. Disediankannya pranata penyelesaian sengketa Pilkada menunjukan bahwa pembentuk Undang-Undang melakukan rekayasa sosial agar masyarakat menempuh pranata yang disediakan secara optimal sehingga sengketa dapat diselesaikan secara tuntas oeh lembaga yang berwenang di tingkatan masingmasing. Ketentuan Pasal 158 juga merupakan bentuk rekayasa sosial, upaya di dalam ketentuan Pasal ini dalam jangka panjang akan membangun budaya hukum dan politik yang erat kaitannya dengan kesadaran hukum yang tinggi. Kesadaran hukum ersebut nantinya akan terlihat apabila selisih suara tidak memenuhi ketentuan dalam Pasal 158 peserta Pilkada tidak mengajukan permohonan pembatalan hasil kepada MK.

6. Terhadap keinginan agar MK mengabaikan ketentuan Pasal 158, menurut MK hal tersebut merupakan kekeliruan karena bertentangan dengan prosedur hukum yang harunya dihormati dan dijunjung tinggi di Indonesia sebagai Negara Hukum. Hal demikian tidak dapat dimaknai bahwa MK mengabaikan penegakan keadilan substantif karena MK akan tetap melakukan pemeriksaan secara menyeluruh terhadap perkara yang memenuhi syarat tenggang waktu (Pasal 157 ayat (5) UU 8/2015), kedudukan hukum (Pasal 158 UU 8/2015), objek permohonan (Pasal 157 ayat (3) dan ayat (4) UU 8/2015), dan jumlam prosentase selisih perolehan suara (Pasal 158 UU 8/2015). 
Dirumuskannya bahwa MK hanya menangani sengketa hasil Pilkada, dan sengketa Pilkada diluar sengketa hasil diselesaikan oleh lembaga lain selain MK. Hal ini dapat dimaknai sebagai penguatan terhadap pengaturan Pasal 158 sebagai pembatas bagi peserta pilkada yang ingin mengajukan permohonan pembatalan hasil Pilkada. Dirumuskannya pranata penyelesaian sengketa pilkada sedemikan rupa membuat para pemohon pembatalan hasil pilkada harus sepenuhnya mampu memenuhi ketentuan Pasal 158. Tidak ada lagi alasan bagi pemohon untuk menuntut kepada MK untuk memeriksa pelanggaran yang bersifat tersetruktur, sistematis, dan masif karena pelanggaran tersebut sudah ditangani di lembaga lain dalam pranata penyelesaian sengketa pilkada. Dengan demikian maka garis kewenangan MK yang diatur secara limitatif dalam Pasal 24C ayat (1) UUD NRI 1945 juga akan semakin jelas karena terkait dengan pelanggaran yang bersifat TSM hanya dapat diperiksa oleh MK dalam perselisihan hasil pemilu, sedangkan Pilkada sendiri berdasarkan Putusan MK Nomor 97/PUU/VII/2013 bukan merupakan rezim pemilu sebagaimana yang dimaksud Pasal 22E ayat (4) UUD NRI 1945.

Pada tahun 2016 atas usulan dari pemerintah yang didasarkan pada hasil evaluasi terhadap penyelenggaraan pilkada serentak pada Desember 2015, dilakukan perubahan kedua atas Undang-Undang Nomor 1 Tahun 2015. Dalam sidang pembahasan perubahan kedua atas Undang-Undang Nomor 1 Tahun 2015, berkaitan dengan Pasal 158 pembentuk Undang-Undang mayoritas cenderung sejalan dengan putusa-putusan MK yang berkaitan dengan batu uji Pasal 158. Pembentuk Undang-Undang berpendapat bahwa dirumuskannya Pasal 158 tersebut ditujukan untuk membangun budaya hukum dan politik yang dewasa serta untuk mengukur kerugian suara yang signifikan. Namun, tujuan baik dirumuskannya Pasal 158 tersebut belum dapat dipahami oleh beberapa pihak. Hal tersebut dikarenakan masih terdapat Pasal yang belum sempurna terkait pengaturan penyelesaian perselisihan Pilkada. Sehingga pada pembahasan tersebut disepakati untuk mempertahankan norma Pasal 158, dengan dibarengi penyempurnaan pasalpasal yang berkaitan dengan proses penyelesaian sengketa pilkada dan penguatan 
lembaga-lembaga yang memiliki kewenangan menyelesaikan sengketa Pilkada. ${ }^{18}$ Pranata penyelesaian sengketa Pilkada yang diatur di dalam Undang-Undang Nomor 8 Tahun 2015 disempurnakan oleh pembentuk Undang-Undang dalam ketentuan Undang-Undang Nomor 10 Tahun 2016. Pembentuk Undang-Undang merubah dan menambahkan ketentuan terkait penyelesaian sengketa Pilkada dalam Undang-Undang Nomor 8 Tahun 2015 dengan tujuan mengoptimalkan lembagalembaga yang menangani sengketa Pilkada, sekaligus memperjelas kewenangan dari masing-masing lembaga. Perubahan dan penambahan tersebut dapat dilihat pada Pasal-Pasal dalam Undang-Undang Nomor 10 Tahun 2016 seperti Pasal 135A, Pasal 144, Pasal 146, Pasal 152, Pasal 153, Pasal 154, Pasal 156, dan Pasal 157. Pasal-Pasal tersebut merumuskan proses penyelesaian perselisihan pilkada secara berjenjang, rigid dengan kewenangan dari masing-masing lembaga yang semakin jelas dalam penanganan perselisihan pilkada. Salah satu Pasal yang perubahannya sangat penting adalah Pasal 135A. Melalui Pasal ini pembentuk undang-undang memperjelas kewenangan dari Bawaslu dalam menangani pelanggaran administrasi dimana yang dimaksud dengan pelanggaran administrasi disini adalah pelanggara yang bersifat terstruktur, sistematis, dan masif (TSM). ${ }^{19}$ Pasal ini semakin menegaskan bahwa MK dalam penanganan sengketa hasil pilkada tidak perlu untuk memeriksa pelanggaran yang bersifat tersturktur, sistematis, dan masif (TSM). Ketentuan ini merupakan bentuk dari penyesuaian terhadap Putusan MK Nomor 123/PHP.BIP-XIV/2016. Ketentuan ini juga memperkuat pengaturan Pasal 158 yang ditujukan untuk mengukur kerugian suara yang signifikan. Dengan design penyelesaian sengketa pilkada sebagaimana telah di sempurnakan dalam Undang-Undang nomor 10 Tahun 2016, maka nantinya pihak yang mengajukan permohonan pembatalan hasil pilkada ke MK merupakan pihak yang benar-benar mengalami kerugian suara secara signifikan.

${ }^{18}$ Risalah Rapat Panja DPR RI, Revisi UU Pilkada Komisi II DPR RI dengan Kemendagri, Kemenkumham, dan Kemenkeu, 21-27 April 2016.

${ }_{19}$ Undang-Undang Nomor 10 Tahun 2016 tentang Pilkada Pasal 135A. 


\section{Akibat hukum pengaturan Pasal 158 UU Nomor 10 Tahun 2016 tentang Pemilihan Kepala Daerah}

\section{Adanya Diskriminasi}

Pengaturan Pasal 158 UU Nomor 10 Tahun 2016 tentang Pilkada menjadikan posisi hak konstitusional warga negara terancam. Pengaturan Pasal 158 membatasi setiap pemohon untuk mengajukan pembatalan penetapan hasil penghitungan Pilkada kepada MK dengan melihat signifikansi kerugian suara. Setiap pemohon harus memenuhi syarat ambang batas yang ditentukan oleh Pasal 158 yaitu 0,5\%2\% kerugian suara yang ditentukan sesuai dengan jumlah masing-masing daerah. Sehingga tidak semua pemohon yang merasa mendapat kerugian suara dapat memohonkan pembatalan hasil penghitungan Pilkada kepada MK. Ditambah MK dalam penanganan sengketa hasil Pilkada ini tidak lagi mempertimbangkan pelanggaran dalam proses Pilkada yang mempengaruhi hasil penghitungan atau dengan kata lain MK hanya mempertimbangkan hasil suara saja. Padahal pada Pasal 28D ayat (1) dengan tegas dijelaskan bahwa setiap warga negara memiliki kedudukan yang sama di hadapan hukum. ${ }^{\mathbf{2 0}}$ Hal tersebut dengan jelas menggambarkan bahwa adanya diskriminasi senhingga mengakibatkan kerugian konstitusial bagi warga negara yang berkontestasi dalam Pilkada.

Penjelasan diatas menggambarkan bahwa adanaya kerugiann konstitusional yang dialami oleh warga negara sebagai peserta pilkada atau warga negara yang memiliki hak untuk dipilih. Pada Pasal 157 UU Nomor 10 Tahun 2016 dijelaskan bahwa yang dimaksud dengan pemohon sengketa hasil Pilkada adalah peserta dari Pilkda itu sendiri. ${ }^{21}$ Namun, diluar kejelasan bahwa peserta Pilkada atau pemohon sengketa hasil Pilkada mengalami diskriminasi dan kerugian konstitusional, warga negara yang memiliki hak untuk memilih secara tidak langsung juga mendapatkan kerugian konstitusional. Di dalam Pasal 1 ayat (2) UUD NRI 1945 dijelaskan bahwa keadulatan berada di tangan rakyat dan dilaksanakan menurut UUD. ${ }^{22}$ Dari pasal

\footnotetext{
${ }^{20}$ Undang-Undang Dasar Negara Republik Indonesia 1945 Pasal 28D ayat (1).

${ }^{21}$ Undang-Undang Nomor 10 Tahun 2016 tentang Pilkada Pasal 157.

22 Undang-Undang Dasar Negara Republik Indonesia 1945 Pasal 1 ayat (2).
} 
tersebut dapat disimpulkan bahwa legitimasi pemerintah berada di tangan rakyat. Ketentuan pasal ini termanifestasi pada sistem pemilihan umum yang melibatkan rakyat untuk memberikan hak suaranya untuk memilih. Pilkada sendiri memamng memiliki perbedaan dengan pemilihan umum lainya. Di dalam kontitusi pemilu secara eksplisit menjelaskan bahwa pemilihan umum dilaksanakan secara langsung dan dilaksanakan dalam kurun waktu 5 tahun sekali sabagaimana termaktub pada Pasal 22E UUD NRI 1945. ${ }^{23}$ Berbeda dengan pengaturan Pilkada dalam konstitusi dimana dalam pelaksanaannya dilaksanakan secara demokratis sebagaimana diatur pada Pasal 18 ayat (4) UUD NRI 1945. ${ }^{24}$ Frasa demokratis pada Pasal 18 ayat (4) tersebut awalnya memang oleh dirumuskan agar dapat bersifat fleksibel dalam arti sistem pemilihan kepala daerah dapat ditentukan oleh pembentuk undangundang dengan menyesuaikan situasi dan kondisi suatu daerah, apakah dapat diselenggarakan secara langsung oleh rakyat atau melalui perwakilan DPRD.

Dalam perkembangannya memang sempat Pilkada dipilih oleh DPRD, namun sekarang Pilkada dilaksanakan dengan langsung dipilih oleh rakyat sebagaimana pengaturan Pasal 1 ayat (1) UU Nomor 10 Tahun 2016. ${ }^{25}$ Dengan bergitu maka kerugian konstitusional tidak diberlakukan sama dihadapan hukum tidak hanya diterima oleh peserta Pilkada sebagai pemohon sengketa hasil Pilkada, namun juga kepada masyarakat daerah yang telah memberikan suara kepada salah satu calon kepala daerah. Selain dengan adanya ambang batas sebagaimana diatur dalam Pasal 158 yang mengakibatkan tidak semua peserta Pilkada sebagai pemohon dapat mengajukan permohonan ke MK. Pasal 158 juga akan mencederai harapan dan hak para pemilih dalam hal ini adalah masyarakat daerah yang telah memberikan suara mereka pada salah satu calon kepala daerah.

Pengaturan mengenai hak pilih warga negara sendiri secara eksplisit diatur di dalam ketentun Pasal 27 ayat (1) dan Pasal 28D ayat (3) UUD NRI 1945. Ketentuan Pasal tersebut menjelaskan bahwa setiap warga negara meimiliki kesempatan yang

\footnotetext{
${ }^{23}$ Undang-Undang Dasar Negara Republik Indonesia 1945 Pasal 22E.

${ }^{24}$ Undang-Undang Dasar Negara Republik Indonesia 1945 Pasal 18 ayat (4).

${ }_{25}$ Undang-Undang Nomor 10 Tahun 2016 tentang Pilkada Pasal 1 ayat (1).
} 
sama dan secara bersama memiliki kedudukan yang sama di dalam hukum dan pemerintahan. ${ }^{26}$ Secara lebih spesifik pada Pasal 47 ayat (1) UU Nomor 39 Tahun 1999 tentang Hak Asasi Manusia dijelaskan bahwa setiap warga negara berhak untuk dipilih dan memilih. Seperangkat regulasi tersebut membuktikan bahwa Indonesia sebagai suatu negara yang tidak membenarkan adanya diskriminasi bagi warga negarannya sekaligus membuktikan bahwa Indonesia merupakan negara yang menjunjung tinggi hak asasi manusia (HAM). ${ }^{27}$ Diluar itu semua memang perlu diingat bahwa masih sangat memunginkan adanya ruang pembatasan untuk menjamin hak dan kebebasan orang lain serta memenuhi tuntutan yang adil sesuai dengan pertimbangan moral, nilai-nilai agama, keamanan dan ketertiban umum dalam bingkai masyarakat yang demokratis sebagai mana Pasal 28J ayat (2) UUD NRI $1945 .^{28}$

\section{Berkurangnya Jumlah Kasus Sengketa Pilkada di Mahkamah Konstitusi}

Sampai 2020 ini sudah terselanggara tiga Pilkada serentak di seluruh Indonesia. Berdasarkan Pasal 201 Undang-Undang Nomor 10 Tahun 2016 Pilkada serentak dilakukan secara berjenjang pada Desember 2015, Februari 2017, Juni 2018, September 2020, dan nantinya Pilkada serentak nasional akan diselenggarakan pada November 2024..$^{29}$ Pilkada serentak pada tahun 2015, 2017, dan 2018 menunjukan bahwa tren jumlah kasus sengketa Pilkada yang ditangani MK semakin menurun.

a. Pemilihan Kepala Daerah Serentak 2015

Pilkada serentak ini diselenggarakan pada 9 Desember 2015 diikuti 269 daerah yang terdiri dari 9 Provinsi, 224 Kabupaten, dan 36 Kota. MK meregistrasi 152 permohonan perkara perselisihan hasil Pilkada. sebanyak 132 perkara diajukan oleh pasangan calon Bupati, sebanyak 13 perkara diajukan oleh pasangan calon Walikota, dan sebanyak 7 perkara diajukan oleh pasangan calon Gubernur. Adapun

${ }^{26}$ Undang-Undang Dasar Negara Republik Indonesia 1945 Pasal 27 ayat (1) dan Pasal 28D ayat (3).

${ }^{27}$ Undang-Undang Nomor 39 Tahun 1999 tentang Hak Asasi Manusia Pasal 47 ayat (1).

${ }^{28}$ Undang-Undang Nomor 39 Tahun 1999 tentang Hak Asasi Manusia Pasal 28J ayat (2).

${ }^{29}$ Undang-Undang Nomor 10 Tahun 2016 tentang Pilkada Pasal 201. 
putusan terhadap perkara tersebut, sebanyak 6 perkara ditarik oleh pemohon, 5 perkara ditolak, sebanyak 3 perkara dikabulkan, dan sebanyak 138 perkara tidak dapat diterima. Terhadap permohonan yang tidak diterima dikarenakan terdapat sebanyak 34 perkara melampaui batas waktu pengajuan permohonan, 1 perkara merupakan pelanggaran administratif, 4 perkara salah objek permohonan, 1 perkara tidak memenuhi ketentuan Pasal 157 ayat (4), 2 perkara diajukan oleh bukan pasangan calon, dan yang paling banyak yaitu 96 perkara tidak memenuhi ketentuan Pasal 158. ${ }^{30}$

b. Pemilihan Kepala Daerah Serentak 2017

Pada Pilkada serentak tahun 2017 terselenggara di 101 daerah terdiri dari 7 Provinsi, 78 Kabupaten, dan 18 Kota. MK meregistrasi perkara perselisihan hasil Pilkada sebanyak 60 permohonan. Pihak yang mengajukan permohonan sebanyak 53 perkara oleh pasangan calon, sebanyak 3 perkara diajukan bakal pasangan calon, 3 perkara diajukan oleh LSM Pemantau, dan 1 perkara oleh perseorangan. Sampai akhir 2017 MK telah memberikan putusan kepada 60 perkara tersebut. Sebanyak 7 perkara ditolak, 2 perkara dikabulkan, dan 51 perkara tidak ditrima. Terhadap putusan yang dinyatakan tidak dapat diterima sebanyak 12 perkara dikarenakan melampaui batas waktu pengajuan permohonan, 3 perkara tidak ada objek, 1 perkara dinyatakan oleh MK untuk meneruskan rekapitulasi suara, 2 perkara dinyatakan tidak memiliki legal standing, dan 33 perkara tidak memenuhi Pasal 158. ${ }^{31}$

c. Pemilihan Kepala Daerah Serentak 2018

Pilkada serentak tahun 2018 diselenggarakan di 171 daerah terdiri dari 17 Provinsi, 115 Kabupaten, dan 39 Kota. MK pada Pilkada serentak ini meregistrasi 72 permohonan perkara perselisihan hasil Pilkada. Sebanyak 66 perkara diajukan oleh pasangan calon dan 5 perkara diajukan oleh bukan pasangan calon. Terhadap perkara yang dimohonkan tersebut, MK memutus sebanyak 2 perkara dikabulkan, 6 perkara ditolak, 1 permohonan ditarik, 61 perkara tidak diterima, dan 2 perkara dinyatakan gugur. Perkara yang dinyatakan tidak dapat diterima sebanyak 5 perkara

\footnotetext{
${ }^{30}$ Kepaniteraan dan Sekretariat Jenderal MK, Laporan Kinerja MK 2016 (2017). [82-83].

${ }^{31}$ Kepaniteraan dan Sekretariat Jenderal MK, Laporan Kinerja MK 2017 (2017).[56].
} 
bukan merupakan kewenangan MK, 17 perkara melewati tenggang waktu, dan 39 perkara dinyatakan tidak memiliki kedudukan hukum sebagaimana diatur dalam ketentuan Pasal 158. ${ }^{32}$

Mahkamah Konstitusi menjadikan ketentuan Pasal 158 sebagai syarat mutlak bagi para pihak untuk mengajukan permohonan sengketa hasil Pilkada. Pada Pilkada serentak tahun 2017 dan 2018 MK sempat menunda penerapan ketentuan Pasal 158 terhadap 6 sengketa. Penundaan tersebut dilakukan terhadap sengketa Pilkada Kabupaten Kepulauan Yapen, Kabupaten Intan Jaya, Kabupaten Tolikara, Kabupaten Puncak Jaya pada 2017, dan Kabupaten Paniai dan Kabupaten Mimika pada Tahun 2018. Penundaan tersebut dilakukan oleh MK karena pertama, objek sengketa hasil Pilkada belum ada disebabkan andanya rekapitulasi suara yang belum selesai dilakukan. Kedua, keputusan KPU tentang pendiskualifiksian calon cacat hukum karena tidak sesuai dengan rekomendasi dari KPU RI dan KPU Provinsi serta Bawaslu RI dan Bawaslu Provinsi. Dengan argumentasi tersebut MK dalam putusan sela memerintahkan agar rekapitulasi suara dilanjutkan dan pemungutan suara ulang. Dalam putusan akhir penerapan ketentuan Pasal 158 tentang ambang batas dilakukan secara mutlak, sehingga terhadap sengketa-sengketa tersebut diputuskan tidak dapat diterima.

Dari Pilkada serentak yang sudah terselenggara sebagaimana diuraikan diatas, dapat dipahami bahwa memang dari Pilkada serentak tahun 2015 sampai 2018 jumlah sengketa perselisihan hasil pilkada yang ditangani MK semakin berkurang. Dalam hal ini penerapan pengaturan Pasal 158 efektif menurunkan jumlah sengketa Pilkada di MK. Stidaknya dapat disimpulkan bahwa penurunan tersebut dapat dimaknai sebagai semakin memahaminnya peserta pilkada terhadap fungsi dari diberlakukannya Pasal 158 sebagai bentuk rekayasa sosial. Artinya peserta Pilkada semakin mangoptimalkan proses pada pranata Pilkada dan lembaga yang sudah terbentuk, seperti KPU, Bawaslu, Gakkumdu, PTUN, dan DKPP sebagai penyelesai sengketa proses Pilkada yang terjadi sebelum nantinya perselisihan hasil Pilkada diselesaikan di MK.

${ }^{32}$ Kepaniteraan dan Sekretariat Jenderal MK, Laporan Kinerja MK 2018 (2018).[42]. 


\section{Penegakan Kepastian Hukum oleh Mahkamah Konstitusi dalam Mengadili Sengketa Hasil Pilkada}

Diketahui bahwa Mahkamah Konstitusi di dalam penanganan sengketa hasil Pilkada berbeda dengan penanganan sengketa hasil Pemilu. Perbedaan tersebut terletak pada cakupan terhadap pelanggaran yang bersifat terstruktur, sistematis dan masif(TSM). Dalam penanganan hasil segketa hasil Pemilu, MK dalam putusannya mencakup pelanggaran dalam proses Pemilu yang memiliki dampak kepada hasil perhitungan atau pelanggaran yang bersifat terstruktur, sistematis dan masif(TSM). Atas dasar itulah pada penanganann sengketa hasil Pemilu Putusan MK memiliki terobosan hukum. Berbeda dengan sengketa hasil Pilkada, MK dalam putusannya tidak mencakup pelanggaran yang bersifat terstruktur, sistematis dan masif (TSM). Hal tersebut didasarkan kepada kekonsistenanya tunduk kepada ketentuan UU Nomor 10 Tahun 2016 tidak terkecuali dalam penerapan ketentuan Pasal 158.

Tunduknya Mahkamah Konstitusi kepada ketentuan UU Nomor 10 Tahun 2016 tidak terkecuali dalam penerapan ketentuan Pasal 158 bukan sesuatu yang tidak berdasar. Hal tersebut didasarkan kepada tidak masuknya Pilkada dalam rezim Pemilu sebagaimana diatur dalam Pasal 22E ayat (4). Tidak masuknya Pilkada dalam rezim Pemilu memberi konsekuensi hukum yang berbeda kepada MK dalam kewenangannya menangani sengketa hasil Pilkada. Ditambah pada ketentuan Pasal 157 ayat (3) yang menjelaskan bahwa kewenangan MK dalam penanganan sengketa hasil Pilkada merupakan kewenangan yang sementara. Kewenangan sementara tersebut disebabkan karena belum terbentuknya Peradilan Khusus sebagai lembaga yang seharusnya berwenang menangani sengketa Pilkada sebagaimana dirumuskan pada ketentuan Pasal 157 ayat (1).

Mahkamah Konstitusi dalam penanganan sengketa hasil Pilkada secara mutlak menerapkan ketentuan Undang-Undang Nomor 10 Tahun 2016 khususnya Pasal 158. Hal tersebut membiaskan penegakan keadilan substantif (substantial justice) yang biasanya ditegakkan oleh MK dalam kewenangannya sebagaimana diatur secara limitatif dalam ketentuan Pasal 24C ayat (1). Kebiasan tersebut disebabkan oleh MK yang secara mutlak menerapkan Pasal 158 dalam artian 
MK tidak melihat pelanggaran didalam proses Pilkada yang mempengaruhi hasil perhitungan. Perlu diketahui bahwa keadilan substantif dalam konteks penyelesaian sengketa hasil Pilkada adalah keadilan yang digali oleh hakim dalam hal ini adalah hakim MK dari rasa keadilan yang ada dalam masyarakat secara demokratis tanpa terpaku pada bunyi pasal dalam UU Pilkada. Artinya keadilan yang dimaksud adalah untuk menegakkan hukum dan menjamin penerapan prinsip Pilkada yaitu langsung, umum, bebas, rahasia, jujur, dan adil. Dengan diterapkannya Pasal 158 secara mutlak MK terkesan tidak menegakkan keadilan substantif.

Biasnya penegakan keadilan substantif juga dapat dilihat dari terkesan dilupakannya beberapa ketentuan didalam konstitusi yang menjadi dasar bagi Mahkamah Konstitusi untuk mengadili suatu perkara atau sengketa, seperti Pasal 24 ayat (1), Pasal 18 ayat (4), dan Pasal 28D ayat (1) UUD NRI 1945. Pertama, pada Pasal 24 ayat (1) UUD NRI 1945 menjelaskan bahwa kekuasaan kehakiman merupakan kekuasaan yang merdeka untuk menyelenggarakan peradilan guna menegakkan hukum dan keadilan. ${ }^{33}$ Dengan diterapkannnya secara mutlak Pasal 158 menyebabkan MK terkesan tidak menjalankan fungsinya sebagai penegak hukum dan keadilan. Kedua, pada Pasal 18 ayat (4) dijelaskan bahwa Kepala Daerah dipilih secara demokratis. ${ }^{34}$ Dalam ketentuan UU Nomor 10 Tahun 2016 dijelaskan bahwa makna dipilih secara demokratis adalah dipilih langsung oleh rakyat dimana dalam penyelenggaraannya dilakukan berdasar prinsip Pilkada yaitu Luberjudil. Dengan diterapkannya secara mutlak Pasal 158 menjadikan MK hanya melihat terpenuhinya ambang batas dan terkesan mengabaikan prinsip Pilkada tersebut. Ketiga, Pada Pasal 28 ayat (1) menjelaskan bahwa setiap orang berhak atas pengakuan, jaminan, perlindungan, dan kepastian hukum yang adil serta perlakuan yang sama dihadapan hukum. ${ }^{35}$ Dengan diterapkannya secara mutlak Pasal 158 menjadikan terabaikannya hak konstitusional warga negara sebagaimana diatur dalam Pasal 28 ayat (1) UUD NRI 1945. Para pemohon sebagai warga negara

\footnotetext{
${ }^{33}$ Undang-Undang Dasasr Negara Republik Indonesia 1945 Pasal 24 ayat (1).

${ }^{34}$ Undang-Undang Dasasr Negara Republik Indonesia 1945 Pasal 18 ayat (4).

35 Undang-Undang Dasasr Negara Republik Indonesia 1945 Pasal 28 ayat (1).
} 
terkesan dikurangi hak konstitusionalnya untuk membuktikan pelanggaran terhadap prinsip Pilkada. Selain itu hak konstitusional para pemohon juga terkesan dilanggar karena tidak diperlakukan sama dihadapan hukum sebagaimana dijelaskan dalam Pasal 28D ayat (1). Dengan kata lain penerapan Pasal 158 ini memberikan ruang adanya diskriminasi terhadap warga negara karena tidak mendapatkan perlakuan yang sama dihadapan hukum.

Penjelasan diatas membuktikan bahwa Mahkamah Konstitusi lebih mengutamakan kepastian hukum di dalam penanganan sengketa hasil Pilkada dan terkesan mengenyampingkan tujuan hukum keadilan dan kemanfaatan. Cita hukum atau tujuan hukum memiliki tiga unsur yang harus terpenuhi secara proporsional yaitu, kepastian hukum, keadilan, dan kemanfaatan. ${ }^{36}$ Tujuan hukum kemanfaatan tidak dapat dicapai apabila tujuan hukum keadilan tidak terpenuhi, hal tersebut dijelaskan di dalam Pasal 28H ayat (2) UUD NRI 1945 yang berbunyi Setiap orang berhak mendapat kemudahan dan perlakuan khusus untuk memperoleh kesempatan dan manfaat yang sama guna mencapai persamaan dan keadilan. ${ }^{37}$

Memang sering terjadi pertentangan atau antinomi antara tujuan hukum keadilan dengan tujuan hukum kepastian. Penulis berpendapat bahwa di dalam penanganan sengketa hasil Pilkada yang ditangani oleh MK ini juga terdapat pertentangan atau antinomi tersebut. Dalam menghadapi pertentangan atau antinomi tersebut peran penerap hukum dalam hal ini MK sangat diperlukan. MK harus mampu memilih antara kepastian atau keadilan. Ketika MK lebih memilih untuk menegakkan kepastian hukum dan mengorbankan keadilan, penulis berpendapat dalam konteks sengketa hasil pilkada ini apa yang dipilih oleh MK adalah tepat.

Prof. Peter Mahmud Marzuki dalam bukunya Pengantar Ilmu Hukum mengemukakan bahwa moral menjadi acuan utama untuk memilih diantara kedua tujuan hukum tersebut. ${ }^{38} \mathrm{MK}$ dalam penanganan sengketa hasil Pilkada khususnya

${ }^{36}$ Fence M. Wantu, 'Antinomi dalam Penegakan Hukum oleh Hakim' (2007)19 Mimbar Hukum.[388].

${ }^{37}$ Undang-Undang Dasasr Negara Republik Indonesia 1945 Pasal 28H ayat (2).

${ }^{38}$ Peter Mahmud Marzuki, Pengant ar Ilmu Hukum (Prenada Media Group 2016).[139]. 
penerapan Pasal 158, menurut penulis sudah menjadikan moral sebagai acuannya. Untuk melihat hal tersebut dapat dilihat dari ratio legis Pasal 158. Pertama, rumusan Pasal 158 dirumuskan oleh pembentuk Undang-Undang untuk rekayasa social sebagai upaya meningkatkan budaya hukum dan politik masyarakat yang lebih dewasa. Disediakannya pranata penyelesaian sengketa pilkada dimana sengketa proses Pilkada diselesaikan pada lebaga diluar MK, sedangkan MK hanya menyelesaikan sengketa hasil menjadi bukti rekayasa sosial tersebut. Melihat rigitnya disain penyelesaian sengketa Pilkada, dimana disain tersebut merupakan relevansi dari ratio legis dirumuskannya Pasal 158, maka ketika MK menegakkan kepastian hukum dengan mempertimbangkan hal tersebut maka MK sudah menjadikan moral sebagai acuan.

Perlu diingat bahwa kewenangan Mahkamah Konstitusi dalam menangani sengketa hasil Pilkada merupakan kewenangan tambahan dan sementara sebagaimana dijelaskan dalam ketentuan Pasal 157 ayat (3) UU Nomor 10 Tahun 2016. Penegakan kepastian hukum oleh MK, ketika MK mengenyampingkan pelanggaran yang bersifat terstruktur, sistematis dan masif (TSM) dengan hanya menerapkan ketentuan Pasal 158 memang dirasa tidak adil bagi para pemohon. Namun, menurut penulis apa yang dilakukan oleh MK sudah tepat. Pendapat penulis tersebut didasarkan pada Putusan MK Nomor 97/PUU-XII/2013 bahwa Pilkada bukan merupakan rezim Pemilu yang berakibat hukum MK tidak lagi berwenang menangani sengketa hasil Pilkada. Ketika kewenangan MK dalam menangani sengketa hasil Pilkada sebagai kewenangan tambahan maka kualifikasi yang diterapkan oleh MK tentunya berbeda. MK tidak lagi menangani sengketa hasil Pilkada sebagaimana kewenangannya diatur secara limitatif pada Pasal 24C ayat (1) UUD NRI 1945. Ditambah pelanggaran yang bersifat terstruktur, sistematis dan masif (TSM) dalam pranata penyelesaian sengketa Pilkada sudah ditangani oleh Bawaslu sebagaimana diatur dalam Pasal 135A UU Nomor 10 Tahun 2016. Dengan dasar tersebut kurang proporsional apabila MK membatalkan penetapan hasil Pilkada oleh KPU dengan dasar pelanggaran terstruktur, sistematis dan masif (TSM). Dengan dasar tersebut pula maka sudah tepatlah pilihan MK untuk 
menegakkan kepastian hukum dalam penanganan sengketa hasil Pilkada.

Dengan dasar yang sama, bahwa pranata penyelesaian sengketa Pilkada sudah dirumuskan secara lengkap dan berjenjang. Melihat pula bahwa penegakan kepastian hukum oleh MK dalam penanganan sengketa hasil Pilkada merupakan hasil pilihan dari pertentangan atau antinomi antara kepastian hukum dengan keadilan dimana hal tersebut wajar didalam penerap hukum dalam menyelesaikan suatu sengketa. Penulis berpendapat dalam konteks penyelesaian sengketa hasil Pilkada, MK tidak dapat sepenuhnya disalahkan. Bahwa banyaknya permohonan sengketa hasil Pilkada kepada MK menunjukan kurang optimalnya lembaga-lembaga penyelesai sengketa Pilkada selain MK. Oleh sebab itu MK sebagai tempat bagi para pemohon untuk melakukan upaya hukum terakhir menjadi bulan-bulanan para pemohon atas dasar keadilan. Padahal, apabila lembaga-lembaga penyelesaian sengketa Pilkada dapat bekerja optimal sesuai dengan kewenangannya, MK tidak akan menjadi lembaga yang terus menerus disalahkan. Perlu diketahui bahwa ratio legis pengaturan Pasal 158 adalah untuk mengukur jumlah signifikansi suara dimana signifikansi suara tersebut menjadi syarat bagi para pemohon untuk melakukan upaya hukum ke Mahkamah Konstitusi. Artinya permohonan pembatalan hasil yang masuk ke MK sudah memiliki kepastian hukum atas perolehan suara yang diperoleh. Ketika MK memilih untuk menegakkan kepastian hukum maka yang dipertimbangkan oleh MK adalah keputusan yang sudah memiliki kepastian hukum dari lembaga terkait, tidak lagi melihat proses sebelum keluarnya keputusan tersebut. Sehingga ketika lembaga penyelesaian sengketa pilkada selain MK tidak secara maksimal melaksanakan kewenangannya, maka yang sangat dirugikan adalah para pemohon sengketa Pilkada.

Dari penjelasan diatas penulis menyimpulkan bahwa apabila penyelesaian sengketa hasil Pilkada masih berada dalam ranah kewenangan tambahan Mahkamah Konstitusi sebagaimana diatur pada Pasal 157 ayat (3) UndangUndang Nomor 10 Tahun 2016, maka pilihan MK untuk menegakkan kepastian hukum khususnya penerapan Pasal 158 adalah tepat. Namun, melihat kurang optimalnya Lembaga penyelesai sengketa proses Pilkada, maka perlu segera 
dibentuk peradilan khusus Pilkada. Jika MK dalam menegakkan kepastian hukum disebabkan oleh kewenangannya diatur secara limitatif oleh konstitusi, maka peradilan khusus kewenangannya tidak limitatif sehingga dapat menegakkan cita hukum yang lebih komprehensif.

\section{Stabilnya Keamanan Nasional}

Keamanan nasional adalah kondisi dan upaya yang menghasilkan keadaan aman dan rasa aman dengan skala luas yang mencakup negara, rakyat, dan segala kepentingannya serta wilayah dengan segenap isi dan kekayaannya. Keamanan nasional juga dapat dirumuskan sebagai kondisi masyarakat, negara, dan sekaligus fungsi penyelenggara keamanan dalam pemerintahan negara yaitu keadaan tegaknya kedaulatan dan hukum Negara. ${ }^{39}$ Keamanan nasional dapat terancam oleh berbagai sebab, dalam konteks penelitian skripsi ini konflik yang terjadi dalam tahapan Pilkada juga mampu mengganggu keamanan nasional.

Berbicara mengenai konflik dalam tahapan Pilkada tidak hanya terjadi pada tahap pencalonan, kampanye, atau penetapan hasil melainkan dapat juga terjadi ketika keluarnya putusan tidak diterimanya permohonan sengketa hasil Pilkada. Dalam catatan peta konflik SNPK dalam kurun waktu antara Pilkada 2005-2014 tercatat terdapat 1.323 insiden kekerasan, 1.172 korban cedera, 53 korban tewas, dan 829 bangunan rusak. ${ }^{40}$ Perlu diingat bahwa konflik Pilkada juga dijadikan alasan oleh MA untuk menolak kewenangan mengadili sengketa hasil Pilkada. MA mengemukakan sebelum tahun 2008 saat sengketa hasil Pilkada masih menjadi kewenangan MA, banyak pengadilan menjadi sasaran amukan masa pendukung calon kepala daerah yang tidak terima dengan putusan pengadilan. ${ }^{41}$

${ }^{39}$ Wahyono S. K., 'Keamanan Nasional dalam Perspektif Baru' (2000) 1 Jurnal Ketahanan Nasional.[21-22].

${ }^{40}$ Islahuddin, 'Jumlah Konflik Bukan Penentu Kerawanan Pilkada' (beritatagar. $i d, 2018)<\mathrm{https}: / /$ beritagar.id/artikel/berita/jumlah-konflik-bukan-penentu-kerawananpilkada $>$ diakses pada 28 Juni 2020.

${ }^{41}$ Risalah Rapat Panja DPR RI, Pembahasan Substansi Materi RUU tentang Perubahan UU No.1 Tahun 2015 (PILKADA), Kamis, 1 Februari 2015.[22-23]. 
Pada tahun 2011 terjadi konflik yang diakibatkan oleh tidak diterimanya putusan Mahkamah Konstitusi yang mengadili sengketa hasil Pilkada di Kabupaten Kotawaringin Barat. Masa yang terlibat dalam konflik Pilkada tersebut merusak fasilitas pemerintah dan juga membakar rumah dinas bupati. Putusan yang menyebabkan konflik tersebut adalah terkait dengan pendiskualifikasian pemenang Pilkada di daerah tersebut akibat adanya praktik politik uang yang terstruktur, sistematis, dan masif (TSM). ${ }^{42}$

Ternyata definisi tentang batu uji terstruktur, sistematis, dan masif (TSM) tidak meiliki definisi yang jelas. Hal tersebut dibuktikan dengan adanya kasus sengketa hasil Pilkada Konawe Selatan dimana MK menyimpulkan telah terjadi money politic namun, MK tidak dapat menilai seberapa banyak uang yang diberikan dan yang diterima dan berapa banyak jumlah penerima. ${ }^{43}$ Artinya MK dalam penanganan sengketa hasil Pilkada menerapkan prinsip terstruktur, sistematis, dan masif (TSM) yang berbeda. Hal tersebut membuktikan tidak adanya kepastian hukum didalam putusan MK yang memiliki batu uji pelanggatan yang terstruktur, sistematis, dan masif (TSM).

Hamdan Zoelfa mengemukakan bahwa untuk mencapai Pilkada yang sesuai dengan kaidah demokrasi maka perlu dilakukan dengan sistem yang baik seperti electoral regulation, electoral process, dan electoral law enforcement. Electoral regulation adalah semua ketentuan Pilkada yang bersifat mengikat dan menjadi pedoman bagi segala pihak yang terkait dengan Pilkada. Electoral law enforcement adalah penegakan hukum atas segala ketentuan atau aturan Pilkada. Sedangkan electoral process adalah semua kegiatan yang berkaitan dengan pelaksanaan Pilkada. ${ }^{44}$ Artinya untuk mencapai sistem Pilkada yang baik diperlukan kepastian hukum didalamnya, yaitu electoral regulation dan electoral law enforcement.

${ }^{42}$ Pusat Penelitian dan Penkajian Perkara, Pengelolaan Teknologi Informasi dan Komunikasi MKRI, Studi Efektivitas Penyelesaian Sengketa Hasil Pemilukada oleh Mahkamah Konstitusi (2012).[15].

${ }^{43}$ Suryanto, 'MK Batalkan Hasil Pilkada Konawe Selatan' (Antaranews.com 2010) $<$ https://www.antaranews.com/berita/207894/mk-batalkan-hasil-pilkada-konawe-selatan> diakses pada 28 Juni 2020.

${ }^{44}$ Hamdan Zoelfa, 'Problematika Penyelesaian Sengketa Hasil Pemilukada oleh Mahkamah Konstitusi' (2013) 10 Jurnal Konstitusi.[381-382]. 
Sejalan dengan itu International Institute for Democracy and Electoral Asistance (IDEA) mengemukakan bahwa suatu sistem yang tidak dapat memberikan kepastian dalam penyelesaian Pemilu dapat menyebabkan konflik. ${ }^{45}$

Penerapan secara mutlak ketentuan Pasal 158 Undang-Undang Nomor 10 Tahun 2016 tentang ambang batas permohonan sengketa hasil pemilihan Kepala Daerah oleh Mahkamah Konstitusi dapat dimaknai sebagai upaya mewujudkan kepastian hukum sekaligus keamanan nasional. Dengan MK tunduk kepada ketentuan UU Nomor 10 Tahun 2016, MK juga sejalan dengan pembentuk UndangUndang sebagaimana ratio legis Pasal 158 yaitu mewujudkan budaya hukum dan politik yang dewasa dengan mengatur pelanggaran Pilkada diselesaikan pada pranata yang sudah disediakan. Dimana MK tidak lagi mempertimbangkan pelanggaran terstruktur, sistematis, dan masif (TSM) dalam memutus sengketa hasil Pilkada. Hal tersebut disebabkan pelanggaran terstruktur, sistematis, dan masif (TSM) sudah menjadi kewenangan Bawaslu di dalam pranata penyelesaian sengketa Pilkada. Dengan pranata penyelesaian sengketa Pillkada tersebut, maka kepastian hukum di dalam sistem penyelenggraan dan penyelesaian sengketa menjadi terjamin. Kepastian hukum tersebut sekaligus juga memberikan jaminan keamanan nasional karena putusan MK terhadap sengketa hasil Pilkada tidak lagi dihadapkan kepada batu uji yang tidak memiliki makna yang jelas seperti pelanggaran terstruktur, sistematis, dan masif (TSM). Dimana salah satu penyebab konflik Pilkada yang terjadi disebabkan oleh hasil putusan MK terhadap sengketa hasil Pilkada.

\section{Kesimpulan}

Ratio legis pengaturan Pasal 158 Undang-Undang Nomor 10 Tahun 2016 tentang Perubahan Kedua Atas Undang-Undang Nomor 1 Tahun 2015 Tentang Penetapan Peraturan Pemerintah Pengganti Undang-Undang Nomor 1 Tahun 2014 Tentang Pemilihan Gubernur, Bupati, Dan Walikota Menjadi Undang-

\footnotetext{
${ }^{45}$ International Institute for Democracy and Electoral Asistance (IDEA), Keadilan Pemilu : Ringkasan Buku Acuan International IDEA (Indonesia Printer 2010).[7].
} 
Undang adalah, pertama mencegah MK terperosok kembali kepada batu uji pelanggaran terstruktur, sistematis dan masif (TSM). Kedua dirumuskannya Pasal 158 awalnya ditujukan untuk mempemudah MA disaat sengketa Pilkada masih menjadi kewenangan MA. Namun, ketika kewenangan sengketa hasil Pilkada kembali kepada MK, Pasal 158 tetap dipertahankan dengan tujuan yang sama yaitu mempermudah MK dalam menangani sengketa hasil Pilkada. Ketiga memperjelas garis kewenangan Mahkamah Konstitusi yang diatur dalam Pasal 24C ayat (1) Undang-Undang Negara Republik Indonesia 1945. Keempat membangun budaya hukum dan politik yang dewasa. Kelima mengoptimalkan lembaga-lembaga penyelesaian sengketa Pilkada. Keenam ditunjukkan untuk mengukur kerugian suara secara signifikan yang dialami oleh calon kepala daerah.

Akibat hukum pengaturan Pasal 158 Undang-Undang Nomor 10 Tahun 2016 adalah pertama, adanya diskriminasi kepada warga negara. Kedua, berkurangnya jumlah kasus sengketa hasil Pilkada yang ditangani oleh MK. Ketiga, pada setiap perkara sengketa hasil Pilkada MK selalu menegakkan kepastian hukum dalam setiap putusannya. Keempat, Pasal 158 yang diterapkan secara mutlak oleh MK menghindarkan MK dari penafsiran yang tidak jelas terhadap pelanggaran Terstruktur Sistematis dan Masif (TSM).

Berdasarkan permasalahan yang sudah dijelasakan saran yang dapat diberikan pada permasalahan tersebut adalah perlu secepatnya dibentuk peradilan khusus yang menangani sengketa Pilkada. Hal tersebut ditunjukan agar MK sebagai lembaga yang sekarang memiliki kewenangan menangani sengketa hasil Pilkada tidak lagi mejadi kambing hitam para pemohon atas dasar keadilan. Hal tersebut juga dapat digunakan untuk mengukur komitmen dari pembentuk undang-undang dalam mewujudkan iklim poitik dan hukum yang dewasa. Dimana pembentuk Undang-undang sudah merumuskan Pasal 157 ayat (1) UU Pilkada yang menjelaskan bahwa sengketa hasil Pilkada diselesaikan pada Peradilan khusus, namun sampai detik ini peradilan khusus tersebut belum juga terbentuk. Dengan juga melihat lembaga penyelesaian sengketa proses Pilkada yang belum optimal maka pembentukan peradilan khusus juga diperlukan untuk menegakan cita hukum yang lebih komperhensif. 


\section{Daftar Bacaan}

\section{Buku}

Parulian Donald, Menggugat Pemilu (Pustaka Sinar Harapan 1997).

Titik triwulan tutik, Kontruksi hukum tata negara indonesia pasca amandemen UUD 1945 (Kencana 2011).

Peter Mahmud Marzuki, Pengant ar Ilmu Hukum (Prenada Media Group 2016).

International Institute for Democracy and Electoral Asistance (IDEA), Keadilan Pemilu : Ringkasan Buku Acuan International IDEA (Indonesia Printer 2010).

\section{Jurnal}

Fence M. Wantu, 'Antinomi dalam Penegakan Hukum oleh Hakim' (2007) 19 Mimbar Hukum.

Wahyono S. K., 'Keamanan Nasional dalam Perspektif Baru' (2000) 1 Jurnal Ketahanan Nasional.

Hamdan Zoelfa, 'Problematika Penyelesaian Sengketa Hasil Pemilukada oleh Mahkamah Konstitusi' (2013) 10 Jurnal Konstitusi.

\section{Lembaga}

Pusat Penelitian dan Pengkajian Mahkamah Konstitusi Republik Indonesia, Tafsir Konstitusional Pelanggaran Pemilukada yang Bersifat Sistematis, Terstruktur dan Masif(2011).

Kepaniteraan dan Sekretariat Jenderal MK, Laporan Kinerja MK 2016 (2017).

Kepaniteraan dan Sekretariat Jenderal MK, Laporan Kinerja MK 2017 (2017).

Kepaniteraan dan Sekretariat Jenderal MK, Laporan Kinerja MK 2018, (2018).

Pusat Penelitian dan Penkajian Perkara, Pengelolaan Teknologi Informasi dan Komunikasi MKRI, Studi Efektivitas Penyelesaian Sengketa Hasil Pemilukada oleh Mahkamah Konstitusi (2012).

\section{Laman}

Nur Azizah Rizki Astuti, 'Pilkada Serentak Digelar 23 September 2020, Ini Tahapannya!' (detik.com, 2020) < detik.com/berita/d-4615384/pilkadaserentak-digelar-23-september-2020-ini-tahapannya>. 
CNN, 'Jumlah Sengketa Pemilu 2019 di MK Bertambah Jadi 340 Kasus' $\quad(C N N \quad$ Indonesia $) \quad<$ https://www.cnnindonesia.com/ nasional/20190531134239-32-400029/jumlah-sengketa-pemilu-2019-di-mkbertambah-jadi-340-kasus $>$.

Islahuddin, 'Jumlah Konflik Bukan Penentu Kerawanan Pilkada' (beritatagar. $i d, \quad 2018)<$ https://beritagar.id/artikel/berita/jumlah-konflik-bukan-penentukerawanan-pilkada>.

Suryanto, 'MK Batalkan Hasil Pilkada Konawe Selatan' (Antaranews.com 2010) $<$ https://www.antaranews.com/berita/207894/mk-batalkan-hasil-pilkadakonawe-selatan>.

\section{Risalah Sidang}

Risalah Rapat Panja DPR RI, Pembahasan subtansi materi RUUtentang Perubahan UU No.1 Tahun 2015 (PILKADA), Kamis, 1 Februari 2015 (2016).

Risalah Rapat Panja DPR RI, Revisi UU Pilkada Komisi II DPR RI dengan Kemendagri, Kemenkumham, dan Kemenkeu, 21-27 April 2016 (2016).

\section{Putusan Pengadilan}

Putusan Mahkamah Konstitusi Nomor 51/PUU-XIII/2015.

Putusan Mahkmah Konstitusi Nomor 58/PUU-XIII/2015.

Putusan Mahkmah Konstitusi Nomor 123/PHP.BUP-XIV/2016.

\section{Perundang-undangan}

Undang-Undang Dasar Negara Republik Indoenesia Tahun 1945.

Undang-Undang Nomor 39 Tahun 1999 tentang Hak Asasi Manusia (Lembaran Negara RI Tahun 1999 Nomor 165, Tambahan Lembaaran Negara Nomor 3886).

Undang-Undang Nomor 12 Tahun 2011 tentang Pembentukan Peraturan PerundangUndangan (Lembaran Negara RI Tahun 2011 Nomor 82, Tambahan Lembaaran Negara Nomor 5234).

Undang-Undang Nomor 10 Tahun 2016 tentang Perubahan Kedua Atas UndangUndang Nomor 1 Tahun 2015 Tentang Penetapan Peraturan Pemerintah Pengganti Undang-Undang Nomor 1 Tahun 2014 Tentang Pemilihan Gubernur, Bupati, Dan Walikota Menjadi Undang-Undang (Lembaran Negara 

Ibnu Rizky: Pembatasan Permohonan Pembatalan...

RI Tahun 2016 Nomor 130, Tambahan Lembaaran Negara Nomor 5898).

Peraturan Mahkamah Konstitusi Nomor 5 Tahun 2017 tentang pedomanm beracara dalam perkara perselisihan hasil pemilihan gubernur, bupati, dan wali kota. 